\title{
Antibacterial Activity of Prismatomeris tetrandra K. Schum Root Extract against Antibiotic Resistance Bacteria ${ }^{\dagger}$
}

\author{
On-Anong SOMSAP \\ Department of Biochemistry, Faculty of Medicine, Princess of Naradhiwas University, \\ Narathiwat 96000, Thailand
}

(Corresponding author’s e-mail: poppy.somsap@gmail.com)

Received: 30 March 2018, Revised: 7 August, 2018, Accepted: 26 August, 2018

\begin{abstract}
Antibiotic resistance bacteria has become an increasing problem now today due to many factors. This study investigates the efficacy of Prismatomeris tetrandra K. Schum root extract as a new source of antibacterial activity for antibiotic resistant bacteria using agar well diffusion method. The results showed that $S$. aureus TISTR517 exhibited more sensitivity to $P$. tetrandra K. Schum root extract than other Gram-positive bacteria indicator strains. On the other hand, Gram-negative bacteria exhibited resistance to $P$. tetrandra K. Schum root extract. The study further showed the activity between $P$. tetrandra K. Schum root extract and gentamycin $(10 \mu \mathrm{g})$, it revealed that MRSA142 was resistant to gentamycin $(10$ $\mu \mathrm{g}$ ) but sensitive to $P$. tetrandra $\mathrm{K}$. Schum root extract. Minimum inhibitory concentration (MIC) and minimum bactericidal concentration (MBC) was evaluated by using S. aureus TISTR517 and MRSA142 as indicator strains. The MIC value was $0.59 \mathrm{mg} / \mathrm{mL}$ and $1.17 \mathrm{mg} / \mathrm{mL}$ for $S$. aureus TISTR517 and MRSA142, respectively. MBC assay demonstrated that the MBC value was $9.75 \mathrm{mg} / \mathrm{mL}$ and $150 \mathrm{mg} / \mathrm{mL}$ for $S$. aureus TISTR517 and MRSA142 respectively. The mode of action was investigated with the presence of $P$. tetrandra $\mathrm{K}$. Schum root extract in the culture broth. The action of $P$. tetrandra $\mathrm{K}$. Schum root extract was revealed of bacteriostatic activity due to the Optical density (OD) at $600 \mathrm{~nm}$ and ColonyForming Units (CFU) of indicator strains were continuously decreased.
\end{abstract}

Keywords: Antibacterial activity, MRSA, mode of action, P. tetrandra K. Schum, S. aureus

\section{Introduction}

The rising of antibiotic resistance of bacteria is a major problem that affects worldwide, especially developing countries. The origin of antibiotic resistance was recorded to show from loss ability of drug for against bacterial growth [1]. Developing of antibiotic resistance may be from many factors such as inappropriate doses of antibiotic during the treatment procedure. Moreover, the antibiotic resistance in human may be continued for a long time.

Plants have been used as an alternative drug because it is providing many kinds of secondary metabolite such as alkaloid, glycoside, flavonoid, quinones and steroids [2]. So, many medicinal plants are used in medicine instead antibiotic drugs against infectious diseases [3]. The author stated that plant extract showed antibacterial activity against Gram-negative bacteria [4]. The leave extract of 9 plant species showed good activity against both Gram-positive (Staphylococcus aureus, Enterococcus faecalis and Bacillus cereus) and Gram-negative bacteria (Escherichia coli, Salmonella typhimurium and Pseudomonas aeruginosa) [5]. Then, the extract of Punica granatum, Syzygium aromaticum, Zingiber officinales, and Thymus vulgaris showing against B. cereus, E. coli, P. aeruginosa and S. typhimurium

\footnotetext{
${ }^{\dagger}$ Presented at the International Conference on Biomedical Sciences 2018: March $22^{\text {nd }}-23^{\text {rd }}, 2018$
} 
http://wjst.wu.ac.th

while only the extract of Cuminum cyminum show efficacy against $S$. aureus [6]. Moreover, leave extract of Arum discoridis exhibited to against 6 antibiotic resistant clinical pathogens [7]. Philippine medicinal plants, namely are Psidium guajava L. and Phyllanthus niruri showing narrow spectrum against Grampositive bacteria while Piper betle L. and Ehretia microphylla Lam. exhibited inhibition both Grampositive and Gram-negative bacteria [8]. Moreover, the extract of Kaempferia pandurata and Senna alata showed the strongest activity against MRSA [9]. Hexane extract of bark of Cinnamomum cassia (L.) J. Presl. (Lauraceae) inhibited the growth of MRSA [10]. From the research of [11] they found that 9 plants extract showing against multidrug resistant bacteria. The dried leaves and vernal stem extract of $S$. dulcis exhibited the highest inhibition zone against $S$. aureus. [12]. The ethanol extract of C. sappan stem exhibited strong antioxidant and antibacterial activities against the 6 pathogenic bacteria [13]

Three southern border provinces of Thailand have a diversity of local and medicinal plants using for treatment of bacterial infections. This study therefore aims to determine the activity of P. tetrandra K. Schum root extract against antibiotic resistance bacteria.

\section{Materials and methods}

\section{Root extract}

P. tetrandra K. Schum was collected from Pattani Province, Thailand. P. tetrandra K. Schum subsp. Malayana (Rigl) J. T. Johanss (BKF no. 194771) is one of medicinal plants used as folk medicine for treating skin diseases in combination with other local plants. Of this, root sample was cleaned with tap water and dried in an oven at $50{ }^{\circ} \mathrm{C}$ for 3 days. Then, the dried materials were reduced to a coarse powder with a blender. Root powder was mixed with $95 \%$ ethanol (ratio 1:4) and incubated at room temperature for 3 days. The mixed was filtered by using cheesecloth and Whatman filter paper No.4. The filtrate was concentrated by rotary evaporator. Subsequently, the total dried weight of root extract was transferred and dissolved with acetone. The solution was finally stored at room temperature for 4 days on the purpose of safe acetone remover. The yield was calculated by a percentage based on root dry weight. Before used, the dry extract was diluted with DMSO.

\section{Bacterial strains and media}

Eight indicator bacterial strains were used such as Staphylococcus aureus (TISTR 517), Bacillus cereus (ATCC 11778), Micrococcus luteus (TISTR 884), Salmonella typhimurium (TISTR292), Escherichia coli (TISTR 887), Escherichia coli (ESBL182), Psuedomonas aeruginosa (TISTR 1467) and MRSA 142. All indicator strains were inoculated on Luria-Bertani agar (LB agar) and incubated at $37^{\circ} \mathrm{C}$ for $18 \mathrm{~h}$. Single pure colony of each indicator strain was picked and transferred into LB broth and incubated at $37^{\circ} \mathrm{C}$ for $18 \mathrm{~h}$.

\section{Antibacterial activity}

The antibacterial activity was determined by agar well diffusion method. The indicator strains used for the antibacterial activity test were displayed in Table $\mathbf{1 .}$

\section{Agar well diffusion method}

Each indicator strain $\left(10^{6} \mathrm{CFU} / \mathrm{mL}\right)$ was inoculated onto the $\mathrm{LB}$ agar plate. Wells with a diameter of $0.6 \mathrm{~cm}$ were cut in the agar using sterile tips. The $P$. tetrandra K. Schum root extract of $100 \mu \mathrm{L}$ (crude extract with $30 \mathrm{mg} / \mathrm{mL}$ ) was then added to each well and allowed to diffuse into the agar during a $5 \mathrm{~h}$ preincubation period at room temperature, followed by aerobic incubation at $37^{\circ} \mathrm{C}$ for $24 \mathrm{~h}$.

Determination of minimum inhibitory concentrations (MIC's) of the P. tetrandra K. Schum root extract

The MIC was determined following the methods described by [6] with slightly modified. MIC is defined as the lowest concentration of the antimicrobial agent that inhibits the microbial growth after $24 \mathrm{~h}$ of incubation. The $P$. tetrandra $\mathrm{K}$. Schum root extract which showing a strong antibacterial activity at 30 $\mathrm{mg} / \mathrm{mL}$ was determined their MIC by using the agar well diffusion method and evaluate their efficiency 
http://wjst.wu.ac.th

in controlling bacterial strains causing antibiotic resistance. The P. tetrandra K. Schum root extract was diluted with DMSO solution to different final concentrations of $1.17,2.34,4.69,9.75,18.75,37.5,75$, 150 and $300 \mathrm{mg} / \mathrm{mL}$. Each indicator strain $\left(10^{6} \mathrm{CFU} / \mathrm{mL}\right)$ was inoculated onto the LB agar plate. Wells with a diameter of $0.6 \mathrm{~cm}$ were cut in the agar using sterile tips. The $100 \mu \mathrm{L}$ of different concentration of $P$. tetrandra K. Schum root extract was added to each well and allowed to diffuse into the agar during a 5 $\mathrm{h}$ pre-incubation period at room temperature, followed by aerobic incubation at $37{ }^{\circ} \mathrm{C}$ for $24 \mathrm{~h}$. The zones of inhibition were measured by Vernier caliper.

Determination of minimum bactericidal concentrations (MBC's) of the effective $P$. tetrandra

\section{K. Schum root extract}

The MBC was determined following the methods described by [6] with slightly modification. The 3 lowest concentrations of the MIC plates of $P$. tetrandra K. Schum root extract not showing the invisible growth of bacteria and then the inhibition zone of theirs were streaked onto sterile LB plates. The plates were aerobic incubated at $37^{\circ} \mathrm{C}$ for $24 \mathrm{~h}$, then determined for bacterial growth in corresponding to $P$. tetrandra K. Schum root extract concentration. The MBC was defined as the lowest concentration of $P$. tetrandra K. Schum root extract that did not exhibiting of bacterial growth.

\section{Mode of action}

The mode of action was according to the method suggested by a previous study [14]. The root extract of $P$. tetrandra K. Schum (final concentration of $30 \mathrm{mg} / \mathrm{mL}$ ) was added in mid-log phase growing cells of $S$. aureus TISTR 517 and MRSA 142 in LB broth. Growing cells of S. aureus TISTR517 and MRSA142 in LB broth without crude protein was used as a control. The optical density of culture broth was recorded at $600 \mathrm{~nm}$ and the number of viable cells was done by plating on LB agar.

\section{Results and discussion}

\section{Antibacterial activity}

The result from the agar well diffusion method showed the inhibitory effect of $P$. tetrandra $\mathrm{K}$. Schum root extract. According to the inhibition zone of each indicator strain shown in Table $\mathbf{1}$ and Figure 1, S. aureus TISTR517 was the most susceptible to $P$. tetrandra K. Schum root extract. This result indicates that the $P$. tetrandra $\mathrm{K}$. Schum root extract had the strongest activity against Gram-positive bacteria. It therefore concludes that the $P$. tetrandra $\mathrm{K}$. Schum root extract showed a narrow inhibitory spectrum against indicator strains. Our finding supported by a previous study showed that Cuminum cyminum extract exhibited a narrow inhibitory spectrum against Gram-positive bacteria [6]. Also, Philippine medicinal plants namely; Psidium guajava L. and Phyllanthus niruri demonstrated a narrow spectrum against Gram-positive bacteria [8]. Our study showed that Gram-negative bacteria resistance to the extract because of its outer membrane consisting of lipopolysaccharide which can protect permeate of substance into the cell [15]. Interestingly, literature reviews reported that composition (e.g., terpenoid, alkaloid and phenolic compound) of the plant extract can interact with protein and enzyme of bacteria cell membrane resulting of damage and leakage of protons into the outer cell and may inhibit amino acid biosynthesis process causing cell death [16]. Moreover, hydrophobicity of the plant extract can interact with protein of microbial cell membrane and mitochondria causing changes of its structure and may also interfere with permeability [17]. In addition, some Gram-negative and Gram-positive bacterial pathogen can produce biofilms formation to protect itself from antibiotic therapy. In Gram-positive bacteria, virulence factors such as toxin, enzyme, adhesion and other protein result in its survival under antibiotic treatment condition [18]. Based on the above findings, it shows antibiotic resistant to bacteria. 
http://wjst.wu.ac.th

Table 1 Antibacterial activity of $P$. tetrandra K. Schum root extract.

\begin{tabular}{clc}
\hline S. no. & Indicator strain & Zone of inhibition (mean of 3 trials) (mm) \\
\hline 1 & B. cereus ATCC 11778 & 21.66 \\
2 & M. luteus TISTR884 & 18.33 \\
3 & S. aureus TISTR517 & 24.00 \\
4 & MRSA142 & 22.00 \\
5 & S. typhimurium TISTR292 & - \\
6 & E. coli TISTR887 & - \\
7 & E. coli ESBL182 & - \\
8 & P. aeruginosa TISTR1467 & - \\
\hline
\end{tabular}

A

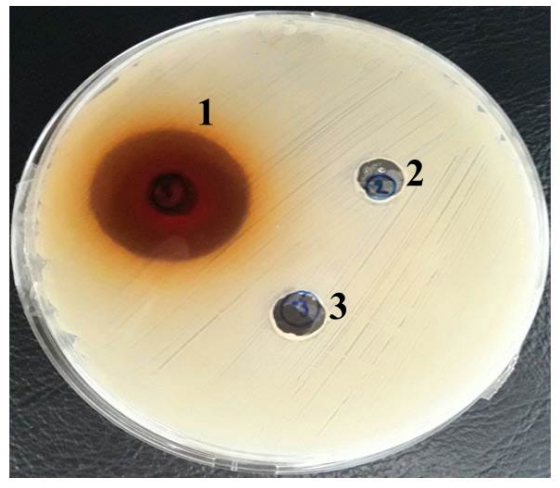

B

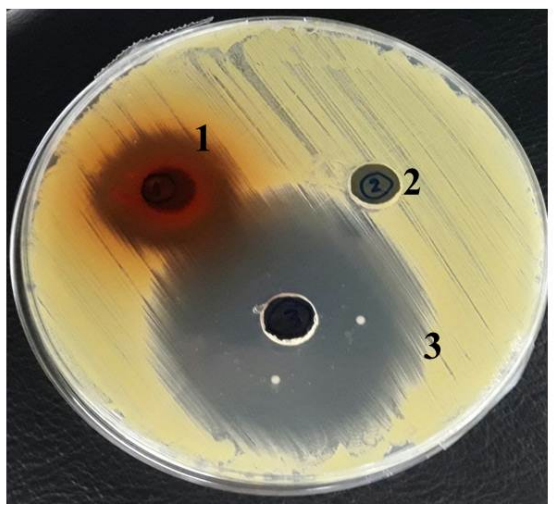

$\mathbf{C}$

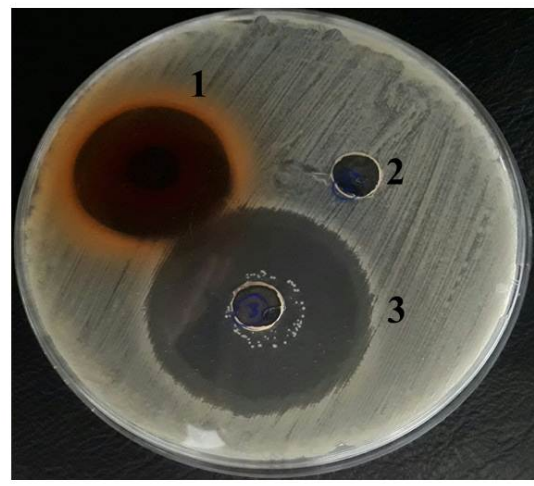

D

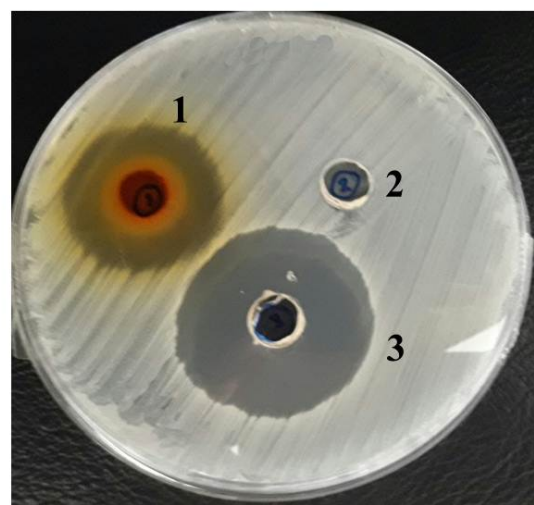

Figure 1 Antibacterial activity of $P$. tetrandra K. Schum root extract (well 1) against A) MRSA142 B) M. luteus TISTR 884 C) B. cereus ATCC11778 D) S. aureus TISTR517 compared with gentamycin (10 $\mu \mathrm{g}$, well 3) and control (DMSO, well 2). 
http://wjst.wu.ac.th

\section{MIC and MBC of $P$. tetrandra $\mathrm{K}$. Schum root extract}

The MIC and MBC assay of $P$. tetrandra $\mathrm{K}$. Schum root extract was determined by agar well diffusion method to evaluate bacteriostatic and bactericidal property. The strongest concentration of $P$. tetrandra K. Schum root extract was reported in Table 2 and Figure 2. MIC value was 0.59 and 1.17 $\mathrm{mg} / \mathrm{mL}$ for $S$. aureus TISTR517 and MRSA142, respectively. This result shown similarly with the MIC of green tea extract exhibited against $S$. aureus ATCC25923 and MRSA were 400 and $400 \mu \mathrm{g} / \mathrm{mL}$, respectively [19]. Leaf extracts of $S$. alata and $K$. pandurata showed the lowest MIC against MRSA were 512 and $256 \mu \mathrm{g} / \mathrm{mL}$, respectively [9]. MBC assay demonstrated that MBC value was 9.75 and 150 $\mathrm{mg} / \mathrm{mL}$ for $S$. aureus TISTR517 and MRSA142, respectively.

Table 2 MIC's and MBC's of $P$. tetrandra K. Schum root extract against $S$. aureus 517 and MRSA142.

\begin{tabular}{lccc}
\hline \multirow{2}{*}{ Root extract } & \multirow{2}{*}{ Conc. $(\mathbf{m g} / \mathbf{m L})$} & \multicolumn{2}{c}{ Zone of inhibition (mean of 3 trials) $(\mathbf{m m})$} \\
\cline { 3 - 4 } & & S. aureus $\mathbf{5 1 7}$ & MRSA142 \\
\hline P. tetrandra K. Schum & 0.15 & 0 & 0 \\
0.29 & 0 & 0 \\
0.59 & 14 & 0 \\
1.17 & 18 & 11 \\
2.34 & 20 & 13 \\
4.69 & 22 & 15 \\
9.75 & 25 & 15 \\
18.75 & 25 & 17 \\
37.50 & 25 & 17 \\
75.00 & 25 & 21 \\
150.00 & 26 & 23 \\
300.00 & 30 & 26 \\
\hline
\end{tabular}

*Diameter of well $=6 \mathrm{~mm} ; *$ All experiments were done in triplicate.

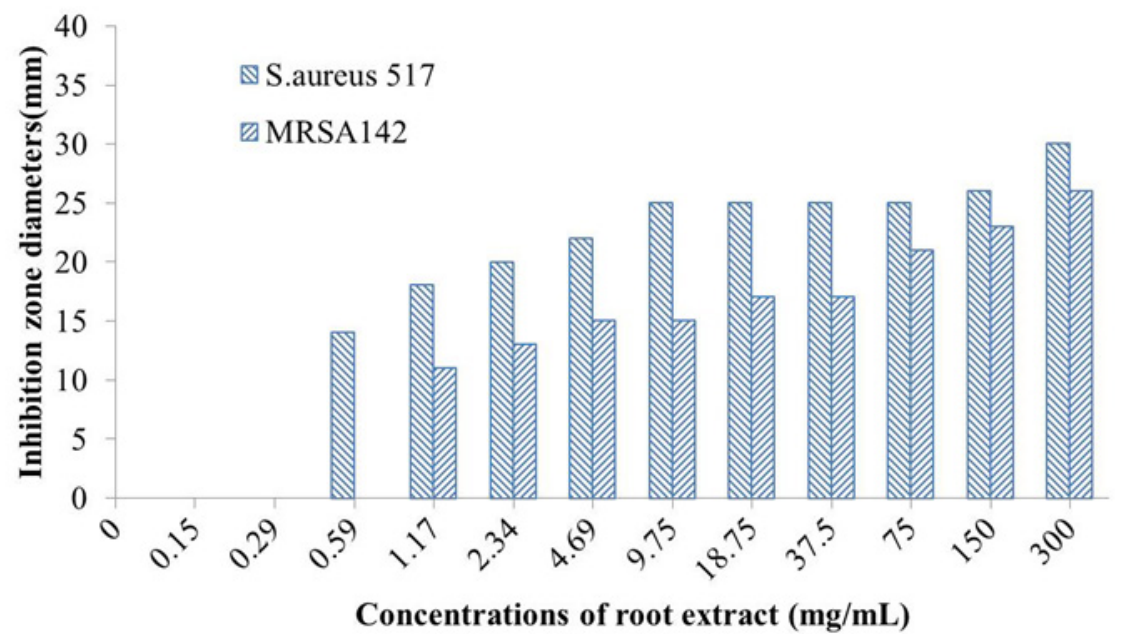

Figure 2 MIC's of P. tetrandra K. Schum root extract against S. aureus 517 and MRSA142. 
http://wjst.wu.ac.th

\section{Mode of action}

This method was initially introduced by $P$. tetrandra K. Schum root extract at $300 \mathrm{mg} / \mathrm{mL}$ concentrations added to mid-log phase of culture medium. Our study found that cell viability of $S$. aureus TISTR517 and MRSA142 were continuously decreased with optical density at $600 \mathrm{~nm}$ and when counting the number of cell viability of indicator strains by plating on LB agar, it caused the reduction in Colony Forming Unit (CFU) of growing cultures with the passage time (Figure 3). From this study, it shows that the mode of action of $P$. tetrandra K. Schum root extract as bacteriostatic activity because number of cell viability of indicator strains were continuously decreased. This result was similarly shown with the action of bacteriocin from Brevibacillus laterosporus SA14 against S. aureus TISTR517 and MRSA142 [20].
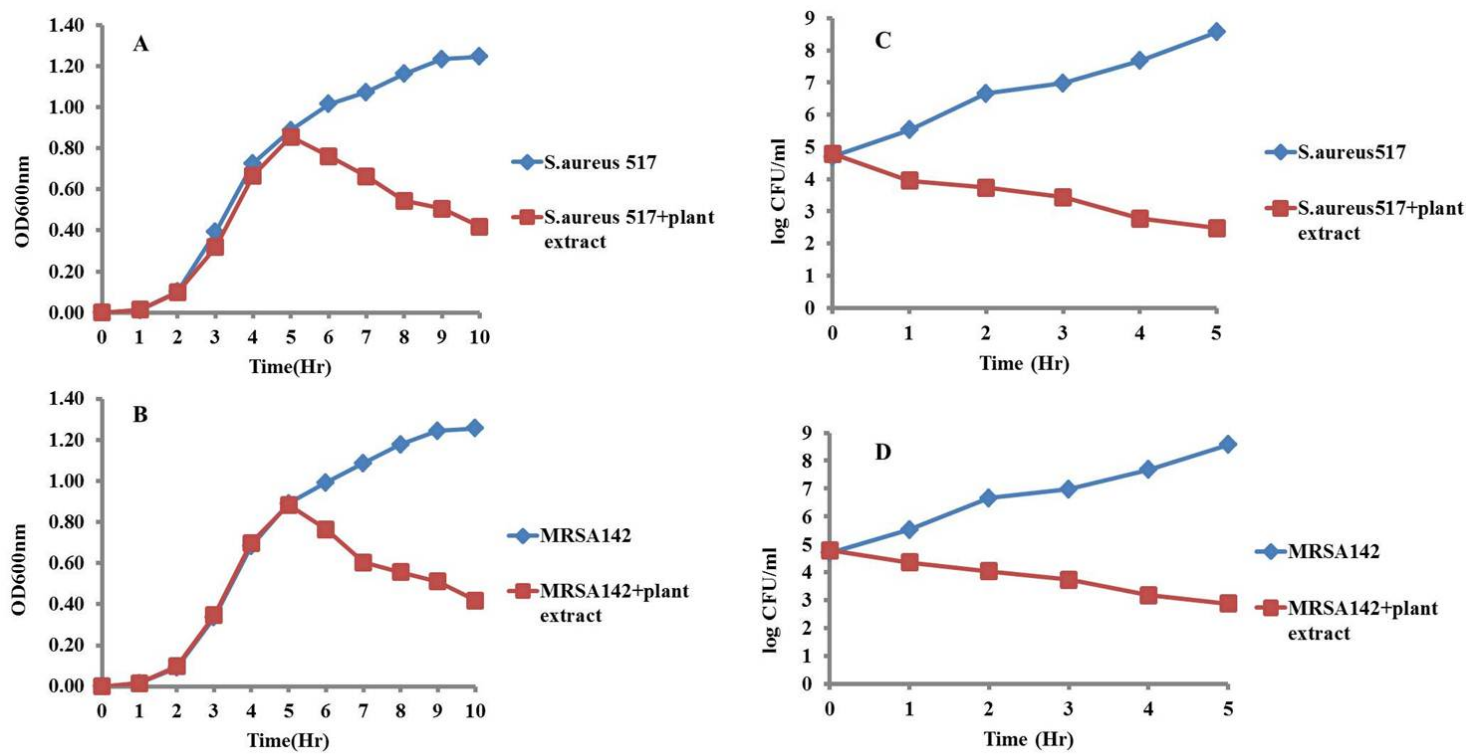

Figure 3 Mode of action of $P$. tetrandra K. Schum root extract to the growing cells of the indicator strains (A, C) S. aureus TISTR517 and (B, D) MRSA142. For control, the culture of indicator strain was grown without $P$. tetrandra $\mathrm{K}$. Schum root extract.

\section{Conclusions}

Based on the results obtained from this study, it was found that Gram-positive bacteria strains exhibited sensitivity to $P$. tetrandra K. Schum root extract. Of this, $S$. aureus TISTR517 was shown a higher sensitivity than other indicator strains. MRSA1424 showed resistance to gentamycin but sensitive to $P$. tetrandra K. Schum root extract while other indicator strains sensitivity to gentamycin. The highest concentration of $P$. tetrandra K. Schum root extract as a bacteriostatic property with MIC value was 0.59 and $1.17 \mathrm{mg} / \mathrm{mL}$ for $S$. aureus TISTR517 and MRSA1424, respectively. This study further showed MBC value was 9.75 and $150 \mathrm{mg} / \mathrm{mL}$ for $S$. aureus TISTR517 and MRSA1424, respectively. The mode of action of $P$. tetrandra K. Schum root extract showed bacteriostatic activity against indicator strains. Therefore, future studies are recommended to investigate the activity of $P$. tetrandra $\mathrm{K}$. Schum root extract on the cytotoxicity, the composition of phytochemical, total phenolic and flavonoid contents. 
http://wjst.wu.ac.th

\section{Acknowledgements}

This work was supported by Faculty of Medicine, Princess of Nadhiwas University. The author would like to thank Assoc. Prof. Dr. Monthon Lertcanawanichakul, School of Allied Health Sciences, Walailak University for supporting bacterial indicator strains and Miss Musleehawatee Worngor, Faculty of Medicine, Princess of Nadhiwas University for supporting P. tetrandra K. Schum root extract.

\section{Reference}

[1] Overview of Bacteria, Available at: https://www.merckmanuals.com/home/infections/bacterialinfections/overview-of-bacteria, accessed June 2017.

[2] K Das, RKS Tiwari and DK Shrivastava. Techniques for evaluation of medicinal plant product as antimicrobial agent: Current methods and future trends. J. Med. Plants Res. 2010; 4, 104-11.

[3] D Singh, R Gupta and SA Saraf. Herbs: Are they safe enough? An overview. Crit. Rev. Food Sci. Nutr. 2012; 52, 876-98.

[4] A Al-Mariri and M Safi. In vitro antibacterial activity of several plant extract and oils against some Gram-Negative bacteria. Iran J. Med. Sci. 2014; 39, 36-42.

[5] IL Elisha, FS Botha, LJ McGaw and JN.Eloff The antibacterial activity of extract of nine plant species with good activity against Escherichia coli against five other bacteria and cytotoxicity of extracts. BMC Compl. Alternat. Med. 2017; 17, 133.

[6] AA Mostafa, AA Al-Askar, KS Almaary, TM Dawoud, EN Sholkamy and MM Bakri. Antimicrobial activity of some plant extracts against bacterial strains causing food poisoning diseases. Saudi. J. Biol. Sci. 2018; 25, 361-6.

[7] M Obeidat, M Shatnawi, M Al-alawi, E Al-Zu’bi, H Al-Dmoor, M Al-Qudah, J El-Qudah and Otri I. Antimicrobial activity of crude extracts of some plant leaves. Res. J. Microbiol. 2012; 7, 59-67.

[8] DL Valle, JI Andrade, JJM Puzon and EC Cabrera. Antibacterial activities of ethanol extracts of Philippine medicinal plants against multidrug-resistant bacteria. Asian Pac. J. Trop. Biomed. 2015, 5, 532-40.

[9] P Wikaningtyas and EY Sukandar. The antibacterial activity of selected plants towards resistant bacteria isolated from clinical specimens. Asian Pac. J. Trop. Biomed. 2016; 6, 16-9.

[10] MS Hossan, H Jindal, S Maisha, CS Raju, SD Sekaran, V Nissapatorn, F Kaharudin, LS Yi, TJ Khoo, M Rahmatullah and C Wiart. Antibacterial effects of 18 medicinal plants used by the Khyang tribe in Bangladesh. Pharm. Biol. 2018; 56, 201-8.

[11] MP Mishra, S Rath, SS Swain, G Ghosh, D Das and RN Padhy. In vitro antibacterial activity of crude extracts of 9 selected medicinal plants against UTI causing MDR bacteria. J. King Saud Univ. Sci. 2017; 29, 84-95.

[12] NB Murugan, BK Mishra and B Paul. Antioxidant and antibacterial evaluation of medicinal plants used in the starter culture (Wanti) of fermented rice beverage in West Garo hills, Meghalaya. $J$. Pharmacogn. Phytochem. 2018; 7, 1669-74.

[13] P Phalanisong, K Vichitphan, J Han and S Vichitphan. High antioxidant and phenolic contents related to antibacterial activity against gastrointestinal pathogenic bacteria of some Thai medicinal plants. Pharmacogn. J. 2018; 10, 341-8.

[14] N Kayalvizhi and P Gunasekaran. Purification and characterization of a novel broad-spectrum bacteriocin from Bacillus licheniformis MKU3. Biotechnol. Bioprocess. Eng. 2010; 15, 365-70.

[15] B Shan, YZ Cai, JD Brooks and H Corke. The in vitro antibacterial activity of dietary spice and medicinal herb extracts. Int. J. Food Microbiol. 2007; 117, 112-9.

[16] AO Gill and RA Holley. Disruption of Escherichia coli, Listeria monocytogenes and Lactobacillus sakei cellular membranes by plant oil aromatics. Int. J. Food Microbial. 2006; 106, 1-9.

[17] BK Tiwari, VP Valdramidi, CPO Donnell, K Muthukumarappan, P Bourke and PJ Cullen. Application of natural antimicrobials for food preservation. J. Agric. Food Chem. 2009; 57, 59876000.

[18] M Frieri, K Kumar and A Boutin. Antibiotic resistance. J. Infect. Public Health 2017; 10, 369-78. 
http://wjst.wu.ac.th

[19] M Radji, RA Agustama, B Elya and CR Tjampakasari. Antimicrobial activity of green tea extract against isolates of methicillin-resistant Staphylococcus aureus and multi-drug resistant Pseudomonas aeruginosa. Asian Pac. J. Trop. Biomed. 2013; 3, 663-7.

[20] OA Somsap and M Lertcanawanichakul. Characteristic and the mode of action of bacteriocin produced by Brevibacillus laterosporus SA14 which isolated from the air. J. Agric. Tech. 2013; 9, 1319-31. 